\title{
Sense of Place and Science Achievement in the Place-Based Science Curriculum
}

\author{
Huei Lee and Chia-Ling Chiang
}

\begin{abstract}
The increasing gap between children's life experience and school science is a worth noting phenomenon in science education. To narrow the gap, the place-based education (PBE), which promotes learning to be rooted in what is local, has been undertaken and emphasized recently. In PBE, students' local community is one of the primary learning resources, so that students' sense of place is an important factor for learning. This study is the first article to explore students' science learning from the sense of place point of view in Taiwan. By using a one-group pretest-posttest design, this study explored students' sense of place and their learning achievement in place-based science teaching. Participants included 21 fifth-grade students of a suburban school in Eastern Taiwan, and the fifth-grade students of other schools in the same township also finished posttest for reference. The results show that the place-based science teaching could enhance not only students' sense of place but their science learning achievement. Besides, students' sense of place is connected with their involvement in community. The longer the students live in the community, the higher their sense of place is. Moreover, the more students participate in community activities, the higher their sense of place is.
\end{abstract}

Index Terms-Learning achievement, PBE, SOP.

\section{INTRODUCTION}

"Examinations guide teaching" is a common phenomenon in Taiwan education. It causes students to disconnect themselves from the real life experiences. In addition, the science curriculum guidelines are based on western science, and the rural-urban or ethnic differences are seldom taken into consideration in textbooks [1]. Smith [2], [3] indicates that educators always mention that "schools are as much the 'real world' as any place else", but there is truth to the judgment that what happens in classrooms is qualitatively different from what happens elsewhere, and it causes students to be unable to apply in daily life what he is learning at school. Kudryavtseva, Stedmana \& Krasnya [4] also pointed out that although environmental education research has embraced the idea of sense of place, it has rarely taken into account environmental psychology-based sense of place literature whose theory and empirical studies can enhance related studies in the education context. Place-based education promotes local culture and environment as the primary resources for learning, constructs learning from daily life, assists students in connecting classrooms with their own communities, and cultivates them

Manuscript received January 30, 2015; revised April 22, 2015.

H. Lee is with the National Dong Hwa University, Hualien, 97401 Taiwan (e-mail: leehuei@mail.ndhu.edu.tw).

C.-L. Chiang was with the National Dong Hwa University, Hualien, 97401 Taiwan (e-mail: clchiang@mail.ndhu.edu.tw). adapting to the change. Influenced by this kind of multiple perspectives, the dimensions of environmental education also extend and change. Therefore, place-based education is a teaching model worth respect and reference, which emphasizes learning rooted in what is local, and response to the local social and environmental issues [5]-[9]. Some scholars [10], [11] also suggest applying the rationale to improve science teaching.

Cresswell [12] suggests place as a way to view, recognize, and understand the world: try to delineate the sense of place (SOP), and connect the gap between human and life by community co-construction. Chinn [6] and [13] also indicate that SOP cultivation is an important factor to promote place-based education successfully. Mueller \& Abrams [14] reviewed the sense of place literature suggests that when a person has a sense of place, her/his relationship between the land and community manifests itself by a person feeling that he/she has a sense of belonging to that place, and he/she demonstrates a deeply felt connection to it.

Semken and his colleague [13], [15], [16] integrated cross-cultural place-based philosophy into the introductory physical geology course offered regularly at Arizona State University. They found that students significantly progressed in place attachment and meaning, and they also indicated that sense of place should be engaged by teachers of place-based science. Besides, they developed a questionnaire making SOP measurable. On the other hand, Jorgensen \& Stedman [17] investigated the lakeshore residents in northern Wisconsin, and developed a high reliability and validity SOP scale to support researches in the future. Continue their research, Qian \& Zhu [18] study urban migrants' sense of place in Guangzhou, China, they suggests that migrants' sense of place demonstrates complex relationships between the three registers of emotional attachment, identity formation and functional dependence.

Research conducted on sense of place, not only the above discussion on environmental education, the other in the neuroscience has also been discussed. Lengena \& Kistemannb [19] searched in neuroscientific literature for ten dimensions which were beforehand identified to be important in a phenomenological sense of place/place identity model: behaviour, body, emotion, attention, perception, memory, orientation, spirituality, meaning/value and culture/sociality. They pointed out that neuroscience has identified many neurobiological correlates of phenomenological observations concerning sense of place. The human brain comprises specific and specialised structures and processes to perceive, memorise, link, assess and use spatial information. Specific parts (hippocampus, entorhinal, parahippocampal and parietal cortex), subregions (parahippocampal place area, lingual landmark area), and cells (place cells, grid cells, 
border cells, head direction cells) have been identified, their specific function could be understood and their interaction traced. Neuroscience has provided evidence that place constitutes a distinct dimension in neuronal processing. This reinforces the phenomenological argumentation of human geography and environmental psychology.

The mental attitude of individuals often forms gradually in childhood. Cresswell [12] pointed that we often have a sense of place about where we live, or where we lived when we were children. Therefore, the issue remains to be understood about how to measure the SOP of primary school students, enhance science learning achievement, and cultivate the SOP. This research investigates the change of science learning achievement and SOP of primary school students after the place-based education science curriculum, and discusses the relevance between student experiences and sense of place, to serve as the concrete suggestions of teachers teaching.

\section{METHOD}

\section{A. Research Design}

One-group pretest-posttest design is taken in this research. The instructional events in place-based curriculum include plant knowledge and local knowledge. The students of experimental group finish the Sense of Place Questionnaire and Science Learning Achievement Questionnaire before and after the four weeks, twelve lessons place-based curriculum as the research treatment. Other fifth grade students in the same township also finish the Sense of Place Questionnaire, to serve as the reference data of posttest. Besides, we also design the interview questions to collect data to analyze the change of students' SOP.

\section{B. Instrument}

Sense of Place Questionnaire: In this research, it takes the structure of sense of place questionnaire developed by [13], to classify the measurement dimensions of SOP into three dimensions as place identity (PI), place attachment (PA), and place dependence (PD). And it's a five-point Likert scale. We also use the interview data to measure the place meaning change of students. The questionnaire is completed after the pilot study (Cronbach's Alpha .937) and revision.

Science Learning Achievement Questionnaire: First, we enumerate the teaching unit concepts. Then we compile items from knowledge, and create a two-way specification table of questionnaire content to analyze the conceptual schema, conceptual content and declarative knowledge statement, to pursue the content validity. The items in pilot study questionnaire are selected by item analysis, which count the difficulty index and discrimination index in each item, and we get the Cronbach's Alpha value for .758.

Interviews: The interviewees include students of experimental group who answer the sense of place questionnaire discordantly in pretest. There are interviews for three times, and five students for each time.

\section{The Treatment (The Instructional Module)}

In this research, the curriculum design is according to one of the unit in textbook "plant content", and combined with place-based curriculum and students' life. Based on the place-based education factors concluded above (student life experience as the instruction basis, takes both local features and history into consideration, student with the ability to learn actively and corporately, support and cooperation from schools and communities, and the identity and guidance of teachers and parents), to cultivate students with knowledge and care of the natural and cultural environment. Besides, there are two field trips in the curriculum (visiting a sugar refinery and a wetland).

\section{RESULTS}

\section{A. Change of $S O P$}

The pretest of SOP: To sum up, the scores of three dimensions are all positive, with the PI 3.56, PA 3.79, and PD 4.11. The PI average is lower, however the PD average is higher, and the difference is statistically significant after one-way ANOVA analysis $\left(.02^{*}, p<.05\right)$. From the interview, we find that students are confused and unsure with the abstract concept, and they express stronger and more obvious mental sustenance and dependence. It has possibly a lot to do with the student age, for they are just fifth-grade, and they have to depend on family and friends. They don't like the unfamiliar environment, and they show more obvious dependence.

The results of independent-samples t tests of SOP (pretest of experimental group students vs. posttest of neighboring school students) are shown in Table I:

TABLE I: INDEPENDENT-SAMPLES $T$ TESTS OF SOP (PRETEST)

\begin{tabular}{ccccccc}
\hline & $n$ & Mean & SD & SE & $t$ & Sig. \\
\hline $\begin{array}{c}\text { experimental } \\
\text { group (pretest) } \\
\text { neighboring } \\
\text { school (posttest) }\end{array}$ & 21 & 57.33 & 7.952 & 1.735 & -.574 & .02 \\
\hline
\end{tabular}

From Table I, the SOP difference of experimental group (pretest) and neighboring school (posttest) students is not statistically significant $(p>.05,95 \% \mathrm{CI})$ whether the equal variances assumed or not. It shows that before the place-based curriculum, there is no statistically significant SOP difference between experimental group and neighboring school students.

The posttest of SOP: After the four weeks place-based science curriculum, the posttest SOP average scores are higher than the pretest. It shows that the township SOP of students is enhanced (Table II).

TABLE II: THE AVERAGE OF SOP (EXPERIMENTAL GROUP)

\begin{tabular}{ccccc}
\hline & PI & PA & PD & Total \\
\hline pretest & 3.56 & 3.79 & 4.11 & 3.82 \\
posttest & 4.20 & 4.26 & 4.41 & 4.29 \\
\hline
\end{tabular}

The use of paired samples $t$ test results of Table III:

TABLE III: PAIRED-SAMPLES T TESTS OF SOP (EXPERIMENTAL GROUP)

\begin{tabular}{cccccc}
\hline & Mean & SD & SE & $t$ & $F$ \\
\hline SOP pretest & 57.33 & 7.952 & 1.735 & & \\
SOP posttest & 64.33 & 4.757 & 1.038 & & \\
$\begin{array}{c}\text { SOP } \\
\text { posttest-pretest }\end{array}$ & 7.000 & 9.143 & 1.995 & 3.508 & $.002^{* * *}$ \\
\hline
\end{tabular}


From Table III, after paired-samples $t$ tests, the difference of SOP between pretest and posttest is statistically significant $(p=.002 * *<.05,95 \% \mathrm{CI})$.

The difference of SOP posttest between the experimental group and neighboring school students is shown in Table IV:

TABLE IV: INDEPENDENT-SAMPLES T TESTS OF SOP (POSTTEST)

\begin{tabular}{lcccccc}
\hline & $n$ & Mean & SD & SE & $t$ & Sig. \\
\hline $\begin{array}{c}\text { experimental } \\
\text { group students } \\
\text { neighboring } \\
\text { school students }\end{array}$ & 21 & 64.33 & 4.757 & 1.038 & $3.494^{* * * *}$ & \\
\hline
\end{tabular}

Max Mean $=75$, Min Mean $=15$

From Table IV, the SOP difference of posttest between experimental group and neighboring school students is statistically significant ( $p<.001,95 \%$ CI) whether the equal variances assumed or not. It shows that after the place-based science curriculum, the experimental group students show stronger SOP than neighboring school students.

\section{B. Science Learning Achievement of Students}

After the four weeks place-based science curriculum, the posttest science learning achievement average scores are higher than the pretest. It shows that the cognitive ability of scientific knowledge of students is enhanced. The results of paired-samples t tests are shown in Table V:

TABLE V: PAIRED-SAMPLES T TESTS OF SCIENCE LEARNING ACHIEVEMENT

\begin{tabular}{ccccc}
\multicolumn{5}{c}{ (EXPERIMENTAL GROUP) } \\
\hline Mean & SD & SE & $t$ \\
pretest & 65.95 & 13.622 & 2.972 & \\
posttest & 81.81 & 16.253 & 3.547 & \\
posttest-pretest & 15.857 & 10.081 & 2.200 & $7.208^{* * * *}$ \\
\hline
\end{tabular}

Max Mean=100, Min Mean=0.

From Table V, after the place-based science curriculum, the difference of science learning achievement between pretest and posttest is statistically significant $(p=.000 * * *<.05$, $95 \% \mathrm{CI}$ ). It shows that the science learning achievement of students is obviously enhanced. To lower the testing effect of one-group pretest-posttest quasi-experimental research, after the four weeks curriculum, we had a discussion with students in the spare time to understand the reasons of their progress furthermore. We find that the cognition and attitude toward the environment of students change in the process of curriculum or after the curriculum. Just as the place-based education methods proposed by Baker \& Knapp [20], the curriculum arrangement provides students with curiosity and questioning attitude. And after understanding the local history, students can reflect and respond to the environmental issue. During the curriculum process, the learning of students also corresponds with the place-based education factors concluded in this research, such as active learning, guidance of teachers and parents, participation of people from community, and cultivation of knowledge and care of the natural and cultural environment.

\section{Correlation between the SOP and Science Learning Achievement in Pretest}

After the bivariate Pearson correlation analysis, we find that there is no correlation between the science learning achievement and SOP in pretest. In the pretest dimension correlation analysis, there is statistically significant correlation between science learning achievement and PD (.828); no statistically significant correlation between science learning achievement and PI/PA. And in the posttest, the correlation between the science learning achievement and SOP is statistically significant (.848). In the posttest dimension correlation analysis, there is statistically significant correlation between science learning achievement and PI (.848); no statistically significant correlation between science learning achievement and PA/PD. The result shows that place-based education can enhance science learning achievement of students, and the correlation between science learning achievement and SOP is statistically significant.

\section{Relationship between the SOP and Students' Background}

The students' background of the experimental group and the other three schools in the same town at post-test SOP use one way ANOVA for analysis:

Relationship between gender and sense of place: The data of students' gender and the SOP as showed in Table VI:

TABLE VI: DATA OF GENDER AND SOP

\begin{tabular}{ccc}
\hline gender & $n$ & Mean \\
\hline boys & 65 & 59.26 \\
\hline girls & 57 & 59.56 \\
\hline
\end{tabular}

The significant between groups are .852, showing the strength of SOP and the gender no significant relationship.

Relationship between school and sense of place: The data of students' school and the SOP as showed in Table VII:

TABLE VII: DATA OF SCHOOL AND SOP

\begin{tabular}{ccc}
\hline School & $n$ & Mean \\
\hline A & 43 & 60.37 \\
\hline B & 44 & 56.73 \\
\hline C & 14 & 57.43 \\
\hline D & 21 & 64.33 \\
\hline
\end{tabular}

The posttest of SOP divided into four schools to analyst, we find the significant among group are $.001 * *<.05$, indicating there are a significant difference on the student's performance in the SOP by students who from different schools, sense of place in the school near downtown present low scores, but the cluster of villages in remote sense of place present higher scores.

Relationship between ethnicity and sense of place: The significant between groups are .361 , showing the strength of SOP and the ethnicity no significant relationship.

Relationship between residence time and sense of place: The data of students' residence time and the sense of place as showed in Table VIII:

TABLE VIII: DATA OF RESIDENCE TIME AND SOP

\begin{tabular}{ccc}
\hline residence time & $n$ & Mean \\
\hline since birth & 75 & 61.01 \\
\hline since primary school & 33 & 58.55 \\
\hline less than two years & 14 & 52.79 \\
\hline
\end{tabular}

The significant between groups are $.000 * * *<.05$, showing 
there are a significant difference on the student's performance in the SOP by students' residence time, the longer residence time, the stronger sense of place performance, and vice versa weaker.

Relationship between the frequency of participation in community activities and sense of place: The data of the frequency of participation in community activities and sense of place as showed in Table IX:

TABLE IX: DATA OF THE FREQUENCY OF PARTICIPATION IN COMMUNITY ACTIVITIES AND SOP

\begin{tabular}{ccc}
\hline frequency of activities & $n$ & Mean \\
\hline Often participate & 14 & 61.14 \\
\hline Occasionally participate & 78 & 58.90 \\
\hline Not participate & 30 & 58.87 \\
\hline
\end{tabular}

Students often participate in community activities, there is stronger sense of place, but occasionally participate or not participate in community activities of these two types of students SOP relatively weak. But significance between groups are .135 , did not reach a significant level.

\section{CONCLUSION}

This study investigated the change of students' sense of place before and after the course is implemented via questionnaire of SOP, and comparison with the neighboring school students, In addition to exploring the current status of SOP foreign students, would like to know whether the curriculum can affect students' sense of place, and what factors influence the strength of students' sense of place. According to the data we obtained the following conclusions:

- Students in the experimental group had significantly enhanced in sense of place.

- Place-based science curriculum will affect the student's sense of place.

- After a place-based science courses, students in all three dimensions of the SOP both enhanced, and the most obvious dimension is place identity.

- Student's gender, race has no effect on SOP, but the school, the residence time has a significant impact.

After four weeks of place-based science curriculum, students participated in activities both in school and out of school, with enthusiastic commentary by community members, and parents discuss with. Students' knowledge learned in addition thought curriculum, but also cultivated by community which also feel intimate relationship with his hometown people and the environment.

\section{IMPLICATION FOR SCIENCE TEACHING}

The field of environmental education has demonstrated an interest in sense of place and related concepts, although it has rarely drawn explicitly on the sense of place literature.[4]

When a new orientation about teaching is proposed, the most frequently challenged is whether this teaching "effective", as well as the new teaching is complex and difficult to proceed. This study shows that the main teaching component in the place-based science curriculum, as same as Smith [2], [3] said that they are inventing a wide range of experiences that allow students to connect what they are learning to their own lives, communities, and regions, lead to children engage a wide range of students in the demands and opportunities of learning. In fact, it is not difficult for most experienced teachers. On the other hand, the development and implementation of place-based science curriculum, not only to promote the growth of sense of place, and be able to combine scientific knowledge with real life, in science learning achievement was promoted as expected, but also reached a basic science the aim of education, that is a combination of science and life.

Cresswell [12] pointed out that people want to change attitude of the use of environment, must be combined with real-life to engaged and acted, involved in the actual accumulated energy from the place (community) in order to discover the relationship between the self, the environment, political culture and each other, in order to further generate essential sense of place and practice. It is an example of the change of students' sense of place in this study. Some scholars are defined place as "local," but in fact this is not just the meaning of place. With the changing times, in a variety of field, "place" is no longer just a narrow definition for the birth and growth of the place, but more broadly to have lived with a particular emotion living space. Through place-based curriculum will help students identify and dependent with the place.

\section{REFERENCES}

[1] C.-J. Guo, "Issues in science learning: An international perspective," in Handbook of Research on Science Education, $1^{\text {st }}$ ed., S. K. Abell and N. G. Lederman, Eds., Mahwah, NJ: Lawrence Erlbaum Associates, 2007, pp. 227-256.

[2] G. A. Smith, "Place-based education: Learning to be where we are," Phi Delta Kappan, vol. 83, pp. 584-594, 2002.

[3] G. A. Smith, "Place-based education: Practices and impacts," in International Handbook of Research on Environmental Education, R. B. Stevenson, M. Brody, J. Dillon, and A. E. J. Wals, Eds., New York: Routledge, 2013, pp. 213-220.

[4] A. Kudryavtseva, R. C. Stedmana, and M. E. Krasnya, "Sense of place in environmental education," Environmental Education Research, vol. 18, pp. 229-250, 2012

[5] P. W. U. Chinn, "Decolonizing methodologies and indigenous knowledge: The role of culture, place and personal experience in professional development," Journal of Research in Science Teaching, vol. 44, pp. 1247-1268, 2007.

[6] P. W. U. Chinn, "Developing teachers' place-based and culture-based pedagogical content knowledge and agency," in Second International Handbook of Science Education, B. J. Fraser, K. Tobin, and C. J. McRobbie, Eds., Springer Netherlands, 2012, pp. 323-334.

[7] D. Sobel, Place-Based Education: Connecting Classrooms and Communities, MA: The Orion Society, 2004.

[8] G. A. Smith and D. Sobel, Place and Community-Based Education in Schools, NY: Routledge, 2010.

[9] R. Yager. (November 11, 2005). Place-based education: What rural schools need to stimulate real learning. [Online]. Available: http://www.ruraledu.org/roots/rr401b.htm

[10] G. S. Aikenhead, A. C. Barton, and P. W. U. Chinn, "Forum: Toward a politics of place-based science education," Cultural Studies of Science Education, vol. 1, pp. 403-416, 2006.

[11] L. Miyoun and C. B. Angela, "Science learning and a sense of place in an urban middle school," Cultural Studies of Science Education, vol. 1, pp. 107-142, 2006.

[12] T. Cresswell, Place: A Short Introduction, MA: Blackwell Publishing Ltd, 2004.

[13] S. Semken and C. R. Freeman, "Sense of place in the practice and assessment of place-based science teaching," Science Education, vol. 92, pp. 1042-1057, 2008. 
[14] Mueller and E. Abrams, "Sense of place: Informing environmental educators," in Proc. NAAEE, Little Rock, October 11-15, 2001, pp. 35-38.

[15] S. C. Semken, C. B. Freeman, N. B. Watts, J. J. Neakrase, and R. E. Dial, "Factors that influence sense of place as a learning outcome and assessment measure of place-based geoscience teaching," Electronic Journal of Science Education, vol. 13, no. 2, 2009.

[16] S. Semken and E. Brandt, "Implications of sense of place and place-based education for ecological integrity and cultural sustainability in diverse places," in Cultural Studies and Environmentalism: The Confluence of Ecojustice, Place-Based (Science) Education, and Indigenous Knowledge Systems, D. J. Tippins, M. P. Mueller, M. van Eijck, and J. D. Adams, Eds., Dordrecht: Springer, pp. 287-302, 2010.

[17] B. S. Jorgensen and R. C. Stedman, "Sense of place as an attitude: Lakeshore owners attitudes toward their properties," Journal of Environmental Psychology, vol. 21, pp. 233-248, 2001.

[18] J.-X. Qian and H. Zhu, "Chinese urban migrants' sense of place: Emotional attachment, identity formation, and place dependence in the city and community of Guangzhou," Asia Pacific Viewpoint, vol. 55 , pp. 81-101, 2014.

[19] C. Lengena and T. Kistemannb, "Sense of place and place identity: Review of neuroscientific evidence," Health \& Place, vol. 18, pp. 1162-1171, 2012.

[20] M. Baker and C. Knapp, "Special focus on place-based education," The Journal of Experiential Education, vol. 27, pp. 265-266, 2005.

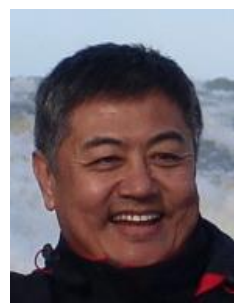

Huei Lee was born in 1957 in Taipei, Taiwan. He earned his bachelor's degree majoring in chemical engineering. Having taught chemistry in high schools for a decade years, he began the master's program in science in 1991, and took his science education $\mathrm{Ph}$ D. degree in 2000. Currently, he is an associate professor and a doctoral supervisor in National Dong Hwa University, Taiwan. His main research interests are focused on science education, chemistry education, rural education, science communication and indigenous science.

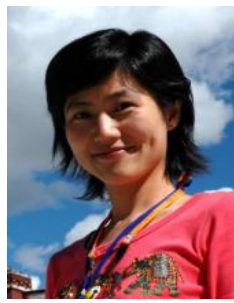

C. L. Chiang is an assistant professor and a doctoral supervisor in National Dong Hwa University, Taiwan.

Her main research interests are focused on science education, especially in peer interaction, power relationship in science classroom, science language, students' identity of science learning, and gender in science. Most of her studies combine theories with practices, cooperatively with teachers in elementary and junior/senior schools. In addition, she also pays attention to astronomy education and population. Not only has she the course of astronomy education in National Dong Hwa University, but also planned and executed observational activities in several schools. 